\title{
Application of Indigenous AMF from ex-coal Mining Soil Combined with Phosphorus Fertilizers to Improved Oil Palm Seedling Growth
} (Elaeis guineensis Jacq.)

\author{
MADE DEVIANI DUAJA ${ }^{1 *}$, ELIS KARTIKA ${ }^{1}$, LIZAWATI $^{1}$ \\ ${ }^{1}$ Faculty of Agriculture, Jambi University \\ Jl. Tri Braya, Pd. Meja, Muaro Jambi, Jambi, Indonesia. 36361 \\ Email: madedevianiduaja@yahoo.com
}

Received 08 September 2018; Received in revised form 16 October 2018; Accepted 23 June 2019; Available online 30 June 2019

\begin{abstract}
Opencast mining caused heavy deforestation and barren land in Jambi. This ex-mining land must be reclaimed by planting crops based on biofertilizers containing mycorrhizae, this is a potential alternative that provides benefit both agronomy plant and ecosystem specially replanting with oil palm. Those are the technology for reclamation ex-coal mining soil. This research aim is to examine the effect of four combinations indigenous isolate of Arbuscular Mycorrhizae Fungi (AMF), which is originated from excoal mining soil that combined with Phosphorous fertilizers to minimize utilizing P fertilizer at oil palm pre-nursery, to improve soil fertility, and seedling growth. Hence, this research was arranged in factorial experiment with 2 factors, using a complete randomized design with three replications. The first factor is five different mycorrhizae isolates, representing a broad range of endomycorrhizae fungi, there are: without indigenous AMF, isolate of Glomus sp. 3, isolates of Glomus sp. 6, isolates of Glomus sp. 15 and isolates of Glomus sp. 16. The second factor is P fertilizer: control (without P fertilizers), fertilizer dosage P 25\%, $50 \%, 75 \%$, and $100 \%$. Variables measured are shoot height, number of leaves per plant, total leaf area per plant, and plant stem diameter. The data were analyzed by analysis of variance to see whether there was an interaction between the MVA isolate and the P fertilizer dosage. The result showed a significant effect on palm oil seedling growth, shoot height, number of leaves per plant, total leaf area per plant but there is no interaction on the stem diameter. Plants that are inoculated with mycorrhizae have greater P content in leaves than those not inoculated. The types of isolated Glomus sp.3 and dosage P 75\% of recommended dosage, give the best seedling growth. This research concluded that inoculation with AMF could minimize $P$ fertilizers doses.
\end{abstract}

Keywords: AMF; inoculated; mining; oil palm; pre-nursery

\section{INTRODUCTION}

Oil Palm is plantation that growth continually until 2018 in Indonesia. The acreage increases for about four times up to 4 million hectares in the last 10 years. It takes a very important contribution to Indonesia economy. The main problem in oil palm plantation is low production (Ermawati \& Saptia, 2013). Average yields produced by Indonesian smallholders are much less than the achievable yields (Euler et al., 2016; Woittiez et al., 2017). In order to increase the production and quality practices such as intensification, area expansion and rehabilitation could be done regularly. In Jambi, expansion area could be done through the utilization of ex-coal mining land since the area is still very widely available. Until 2018, continuous coal mining still practiced that caused barren land increased. Various attempts have been made to utilize the soil and to replanting the barren land, especially with oil palm. Sustainable practices in the oil palm plantation involved careful fertilizers management is needed to reduce excess application over the required amount in the field (Basiron, 2007; Webb, 2009). The application of mycorrhizal technology combined with phosphorus fertilizers to increase oil palm growth and production is one of the strategic alternatives.

Oil palm needs high nutrient, mineral content and water, particularly in the early stages (pre-nursery) (Wahid et al., 2005; Sun et al., 2011). Thus, a typical management practice should use high rates of $P$ fertilizers. $P$ fertilizer combined with AMF provided benefit to 
increase crop root system with many root hairs (Acevedo et al., 2014; Ramos-Zapata et al., 2009). This has a positive effect for oil palm with a poorly developed root system. It has no root hairs which caused oil palm not adequately able to take up enough $\mathrm{P}$ without $\mathrm{AMF}$ assistance.

Phosri et al. (2010) stated to improve growth and development of oil palm may initiate with high levels of $\mathrm{P}$ fertilizers, but the right dose must be considered because it will inhibit the development of mycorrhizae symbiosis. Hence, plants growth poorly because the plant cannot take up more P. AMF studies proved that responses to AMF fungal species vary with different host plant species (Gaur and Adholeya, 2002; Eom et al., 2000), and therefore, several species should be screened to ensure they are compatible outcome with the plant. According to Liu et al. (2007), native and selected strains of the same taxonomic species can give different responses in the plants as well. This study was undertaken to investigate the responses of oil palm seedling to the four isolated indigenous AMF combined with phosphorus fertilizers that could increase oil palm seedling growth and reduced mineral fertilizer at ex-coal mining soil.

\section{MATERIALS AND METHODS}

The oil palm pre-nursery experiment had been conducted at Teaching and Research
Farm, Agriculture Faculty, Jambi University, Jambi. The research used factorial experiment which arranged as completely randomized design with three replications. The first factor is the Mycorrhizae Isolate (AMF indigenous) which consist of five levels: none of indigenous AMF inoculation, isolate of Glomus sp. 3, isolates of Glomus sp. 6, isolates of Glomus sp. 15, and isolates of Glomus sp. 16. The second factor is the doses of $\mathrm{P}$ fertilizer, which consists of 5 levels: without $\mathrm{P}$ fertilizer, fertilizer with $25 \%, 50 \%, 75 \%$ and $100 \%$ recommended doses. The growth variables measured were seedling height, stem diameter, number of leaves and total seedling leaf area. The data obtained were analyzed by analysis of variance to see whether there was an interaction between the isolate and the $\mathrm{P}$ fertilizer doses. Then analyzed with Duncan Multiple Range Test. All statistical analyses were run in SPSS. Significant results are shown with at $\mathrm{P}<0.05$.

\section{RESULT AND DISCUSSION}

Seedling Height. There was interaction between mycorrhizae isolates and the $\mathrm{P}$ dose on the palm oil seedlings height. The highest height was obtained at the combinations of isolate Glomus sp. 3 and $75 \%$ of P doses. This was followed by the plant of none AMF with $\mathrm{P}_{1}$. The lowest plant height was achieved at $\mathrm{m}_{3}$ $\mathrm{p}_{2}$ (Glomus sp.15 with $50 \%$ of $\mathrm{P}$ doses). The results were described in Table 1.

Table 1. Average of palm oil seedling height at every combination of mycorrhizae isolate and $\mathrm{P}$ doses of recommended

\begin{tabular}{|c|c|c|c|c|c|c|}
\hline \multirow{2}{*}{ Mycorrhizae Isolate } & \multicolumn{5}{|c|}{ P Doses } & \multirow{2}{*}{ Average } \\
\hline & $\mathrm{p}_{0}$ & $\mathrm{p}_{1}$ & $\mathrm{p}_{2}$ & $\mathrm{p}_{3}$ & $\mathrm{p}_{4}$ & \\
\hline \multirow[t]{2}{*}{$\mathrm{m}_{0}$} & $20.55 \mathrm{a}$ & $23.50 \mathrm{a}$ & $20.40 \mathrm{a}$ & $21.12 \mathrm{a}$ & $20.68 \mathrm{a}$ & $21.25 \mathrm{~A}$ \\
\hline & A & A & A & A & A & \\
\hline $\mathrm{m}_{1}$ & $\begin{array}{c}20.52 \mathrm{a} \\
\mathrm{A}\end{array}$ & $\begin{array}{c}19.22 \mathrm{a} \\
\mathrm{A}\end{array}$ & $\begin{array}{c}21.75 \mathrm{a} \\
\mathrm{A}\end{array}$ & $\begin{array}{c}26.00 \mathrm{~b} \\
\mathrm{~B}\end{array}$ & $\begin{array}{c}23.20 \mathrm{a} \\
\mathrm{A}\end{array}$ & $22.14 \mathrm{~A}$ \\
\hline $\mathrm{m}_{2}$ & $\begin{array}{c}20.28 \mathrm{a} \\
\mathrm{A}\end{array}$ & $\begin{array}{c}19.55 \mathrm{a} \\
\mathrm{A}\end{array}$ & $\begin{array}{c}22.53 \mathrm{a} \\
\mathrm{A}\end{array}$ & $\begin{array}{c}21.57 \mathrm{a} \\
\mathrm{A}\end{array}$ & $\begin{array}{c}19.77 \mathrm{a} \\
\mathrm{A}\end{array}$ & $20.74 \mathrm{~A}$ \\
\hline $\mathrm{m}_{3}$ & $\begin{array}{c}20.57 \mathrm{a} \\
\mathrm{A}\end{array}$ & $\begin{array}{c}22.00 \mathrm{~b} \\
\mathrm{~A}\end{array}$ & $\begin{array}{c}16.30 \mathrm{a} \\
\mathrm{A}\end{array}$ & $\begin{array}{c}20.25 \mathrm{a} \\
\mathrm{A}\end{array}$ & $\begin{array}{c}19.62 \mathrm{a} \\
\mathrm{A}\end{array}$ & $19.75 \mathrm{~A}$ \\
\hline $\mathrm{m}_{4}$ & $\begin{array}{c}22.25 \mathrm{a} \\
\mathrm{A}\end{array}$ & $\begin{array}{c}22.93 \mathrm{a} \\
\mathrm{A}\end{array}$ & $\begin{array}{c}21.28 \mathrm{a} \\
\mathrm{A}\end{array}$ & $\begin{array}{c}19.28 \mathrm{a} \\
\mathrm{A}\end{array}$ & $\begin{array}{c}18.42 \mathrm{a} \\
\mathrm{A}\end{array}$ & $20.83 \mathrm{~A}$ \\
\hline Average & $20.83 \mathrm{a}$ & $21.44 \mathrm{a}$ & $20.452 \mathrm{a}$ & $21.64 \mathrm{a}$ & $20.33 \mathrm{a}$ & \\
\hline
\end{tabular}

Number in row followed by the different letter (lowercase) and number within a column with uppercase were significantly different at $\mathrm{P} \leq 0.05$ using Duncan Multiple Range Test (DMRT)

This result has shown that indigenous isolate Glomus sp. 3 that compatible with palm oil. The symbiosis can increase palm oil seedling growth. AMF has some symbiotic associations that formed between plants and soil fungi that takes an essential role in plant 
growth, and improved soil quality that benefits for both associations. Bucher (2007) said that AMF symbiosis is a natural association between the roots of higher plants and can improve the host plants growth and the acquisition of nutrients, especially $\mathrm{P}$ from soil.

Seedling Stem Diameter. The highest seedling stem diameter was obtained by the combination $\mathrm{m}_{1} \mathrm{p}_{3}\left(\mathrm{~m}_{1}\right.$ : Mycorrhizae isolate Glomus sp. 3, m3: 75\% of Phosphorous doses). This was followed by $\mathrm{m}_{\mathrm{o}} \mathrm{p}_{1}$ (Glomus $\mathrm{sp} .15$ with $50 \%$ of $\mathrm{P}$ doses) (Table 2). The responses of plants to environments are shown by plant height and stem diameter. The highest stem diameter has shown that Glomus sp. 3 was compatible with palm oil seedling.

Table 2. Average of palm oil seedling stem diameter at every combination of mycorrhizae isolate and $\mathrm{P}$ doses of recommended

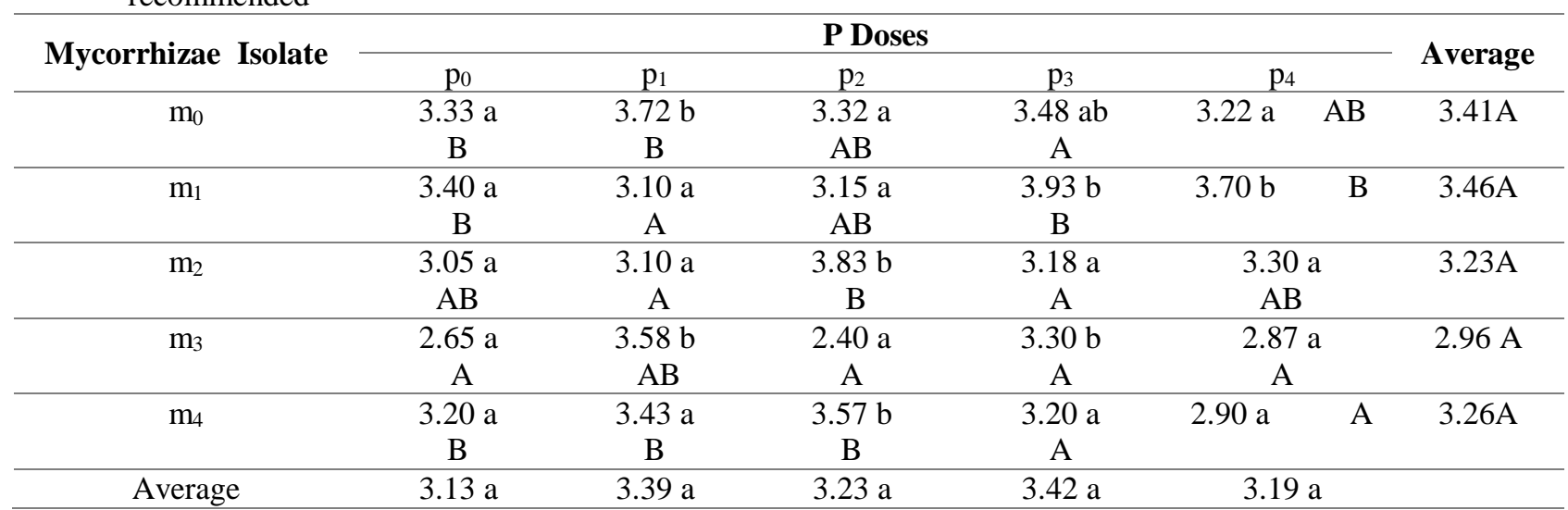

Number in row followed by the different letter (lowercase) and number within a column with uppercase were significantly different at $\mathrm{P} \leq 0.05$ using Duncan Multiple Range Test (DMRT)

Once the symbiotic association between oil plant and a mycorrhizae species was established for a host species, the symbiosis is a mutualistic effect and significant to increase plant height, stem diameter, and plant biomass.
Number of Seedling Leaf. The highest numbers of seedling leaf were obtained by the combination of $m_{1} p_{1}$ (Table 3), even although there is no interaction between indigenous isolate AMF and Phosphorus doses.

Table 3. Average of palm oil palm seedling leaves number at every combination of mycorrhizae isolate and $\mathrm{P}$ of recommended doses

\begin{tabular}{|c|c|c|c|c|c|c|}
\hline \multirow{2}{*}{ Mycorrhiza Isolate } & \multicolumn{5}{|c|}{ Doses $\mathbf{P}$} & \multirow{2}{*}{ Average } \\
\hline & $\mathrm{p}_{0}$ & $\mathrm{p}_{1}$ & $\mathrm{p}_{2}$ & $\mathrm{p}_{3}$ & $\mathrm{p}_{4}$ & \\
\hline $\mathrm{m}_{0}$ & $3.67 \mathrm{~b}$ & $3.67 \mathrm{~b}$ & $3.50 \mathrm{ab}$ & $3.17 \mathrm{a}$ & $3.17 \mathrm{a}$ & $3.43 \mathrm{~A}$ \\
\hline & A & A & $\mathrm{AB}$ & A & A & \\
\hline $\mathrm{m}_{1}$ & $\begin{array}{c}3.33 \mathrm{a} \\
\mathrm{A}\end{array}$ & $\begin{array}{c}3.83 \mathrm{~b} \\
\mathrm{~B}\end{array}$ & $\begin{array}{c}3.50 \mathrm{ab} \\
\mathrm{AB}\end{array}$ & $3.79 \mathrm{~b} \mathrm{~B}$ & $\begin{array}{c}3.33 \mathrm{a} \\
\mathrm{AB}\end{array}$ & $4.45 \mathrm{~B}$ \\
\hline $\mathrm{m}_{2}$ & $\begin{array}{c}3.33 \mathrm{ab} \\
\mathrm{A}\end{array}$ & $\begin{array}{c}3.17 \mathrm{a} \\
\mathrm{A}\end{array}$ & $\begin{array}{c}3.67 \mathrm{~b} \\
\mathrm{~B}\end{array}$ & 3.17 a $\mathrm{A}$ & $\begin{array}{c}3.50 \mathrm{~b} \\
\mathrm{~B}\end{array}$ & $3.37 \mathrm{~A}$ \\
\hline $\mathrm{m}_{3}$ & $\begin{array}{c}3.50 \mathrm{ab} \\
\mathrm{A}\end{array}$ & $\begin{array}{c}3.67 \mathrm{~b} \\
\mathrm{AB}\end{array}$ & $\begin{array}{c}3.17 \mathrm{a} \\
\mathrm{A}\end{array}$ & $\begin{array}{c}3.50 \mathrm{ab} \\
\mathrm{AB}\end{array}$ & $\begin{array}{c}3.50 \mathrm{ab} \\
\mathrm{B}\end{array}$ & $3.47 \mathrm{~A}$ \\
\hline $\mathrm{m}_{4}$ & $\begin{array}{c}3.67 \mathrm{c} \\
\text { A }\end{array}$ & $\begin{array}{c}3.50 \mathrm{ab} \\
\mathrm{A}\end{array}$ & $\begin{array}{c}3.50 \mathrm{ab} \\
\mathrm{AB}\end{array}$ & $\begin{array}{c}3.50 \mathrm{ab} \\
\mathrm{AB}\end{array}$ & $\begin{array}{c}3.33 \mathrm{a} \\
\mathrm{AB}\end{array}$ & $3.50 \mathrm{~A}$ \\
\hline
\end{tabular}

Number in row followed by the different letter (lowercase) and number within a column with uppercase were significantly different at $\mathrm{P} \leq 0.05$ using Duncan Multiple Range Test (DMRT)

This research shown that, Indigenous AMF, isolate Glomus sp. 3 trend was the most compatible mycorrhizal species, which was established with oil palm as the host plant, therefore, the symbiosis shown an increase in leaf production.

Total Seedling leaf Area. The highest number of total leaf seedling was obtained by the combination $\mathrm{m}_{1} \mathrm{p}_{3}$. This research shows that 
inoculation indigenous AMF, isolate Glomus sp.3, was increased oil palm growth. Then symbiotic relationship between AMF and roots of higher plants contributes significantly to plant nutrition and its growths (Amaya-Carpio et al., 2009).

Table 4. Average of oil palm seedling total leaves area at every combination of mycorrhizae isolate and $\mathrm{P}$ of recommended doses

\begin{tabular}{|c|c|c|c|c|c|c|}
\hline \multirow{2}{*}{ Mycorrhiza Isolate } & \multicolumn{5}{|c|}{ Doses P } & \multirow{2}{*}{ Average } \\
\hline & $\mathrm{p}_{0}$ & $\mathrm{p}_{1}$ & $\mathrm{p}_{2}$ & $\mathrm{p}_{3}$ & $\mathrm{p}_{4}$ & \\
\hline $\mathrm{m}_{0}$ & $\begin{array}{c}81.63 \mathrm{~b} \\
\mathrm{~B}\end{array}$ & $\begin{array}{c}93.83 \mathrm{c} \\
\mathrm{B}\end{array}$ & $\begin{array}{c}56.80 \mathrm{a} \\
\mathrm{A}\end{array}$ & $\begin{array}{c}87.56 \mathrm{c} \\
\text { B }\end{array}$ & $\begin{array}{c}71.39 \mathrm{~b} \\
\mathrm{~A}\end{array}$ & $78.24 \mathrm{~B}$ \\
\hline $\mathrm{m}_{1}$ & $\begin{array}{c}72.52 \mathrm{ab} \\
\mathrm{A}\end{array}$ & $\begin{array}{c}61.80 \mathrm{a} \\
\mathrm{A}\end{array}$ & $79.46 \mathrm{~b} \mathrm{AB}$ & $\begin{array}{c}66.18 \mathrm{a} \\
\mathrm{A}\end{array}$ & $\begin{array}{c}82.67 \mathrm{c} \\
\mathrm{B}\end{array}$ & $72.53 \mathrm{~A}$ \\
\hline $\mathrm{m}_{2}$ & $\begin{array}{c}69.37 \mathrm{a} \\
\mathrm{A}\end{array}$ & $\begin{array}{c}63.27 \mathrm{a} \\
\mathrm{A}\end{array}$ & $\begin{array}{c}90.61 \mathrm{c} \\
\mathrm{B}\end{array}$ & $\begin{array}{c}71.39 \mathrm{~b} \\
\mathrm{~A}\end{array}$ & $\begin{array}{c}64.27 \mathrm{a} \\
\mathrm{A}\end{array}$ & $71.78 \mathrm{~A}$ \\
\hline $\mathrm{m}_{3}$ & $\begin{array}{c}71.50 \mathrm{~b} \\
\mathrm{~A}\end{array}$ & $\begin{array}{c}72.69 \mathrm{~b} \\
\mathrm{~A}\end{array}$ & $\begin{array}{c}53.61 \mathrm{a} \\
\mathrm{A}\end{array}$ & $\begin{array}{c}79.90 \mathrm{~b} \\
\mathrm{AB}\end{array}$ & $\begin{array}{c}74.48 \mathrm{~b} \\
\mathrm{~A}\end{array}$ & $70.44 \mathrm{~A}$ \\
\hline $\mathrm{m}_{4}$ & $\begin{array}{c}73.28 \mathrm{~b} \\
\mathrm{~A}\end{array}$ & $\begin{array}{c}84.16 \mathrm{c} \\
\text { B }\end{array}$ & $\begin{array}{c}82.86 \mathrm{c} \\
\mathrm{B}\end{array}$ & $\begin{array}{c}57.92 \mathrm{a} \\
\mathrm{A}\end{array}$ & $\begin{array}{c}65.66 \mathrm{a} \\
\mathrm{A}\end{array}$ & $72.78 \mathrm{~A}$ \\
\hline Average & $73.66 \mathrm{a}$ & $75.05 \mathrm{a}$ & $72.67 \mathrm{a}$ & $72.59 \mathrm{a}$ & $71.69 \mathrm{a}$ & \\
\hline
\end{tabular}

Number in row followed by the different letter (lowercase) and number within a column with uppercase were significantly different at $\mathrm{P} \leq 0.05$ using Duncan Multiple Range Test (DMRT)

These positive responses in productivity to AMF colonization have been mainly attributed to enhanced up taken by AMF of relatively immobile soil ion such as phosphorus (Liu et al., 2007). The positive effect of Glomus sp. colonization on plant growth was observed by reference (Dreyer et al., 2008; Ruiz-Lozano \& Azcón, 2000; Jaiti et al., 2007). The arbuscular mycorrhizae fungi supply nutrient to their host plant, especially phosphorus (Joner et al., 2000). The fungi absorb phosphate from the soil through their extra radicle hyphae and incorporate it into cytosolic pool, while the excess of phosphorus is transferred to the vacuoles and translocation to the intra radicle hyphae.

\section{CONCLUSION}

The result shows that, the isolated Glomus sp. 3 combined with $75 \% \mathrm{P}$ doses reduced from recommended doses showed highly effective to promoting oil palm growth seedling. The total leaf area and seedling height, which were inoculated with these fungal being increased, compared with non-inoculated plants. Therefore, rationale for indigenous AMF application in the pre-nursery seems highly warranted coupled with the reduction in the amounts of $\mathrm{P}$ given to the seedling. Furthermore, there is a potential indigenous
AMF application and could reduce in $\mathrm{P}$ fertilizers especially in oil palm at pre-nursery.

\section{REFERENCES}

Acevedo E, Galindo-Castañeda T, Prada F, Navia M, Romero HM. 2014. Phosphatesolubilizing microorganisms associated with the rhizosphere of oil palm (Elaeis guineensis Jacq.) in Colombia. Applied Soil Ecology. vol 80: 26-33. doi: https://doi.org/10.1016/j.apsoil.2014.03.01 1.

Amaya-Carpio L, Davies Jr FT, Fox T, He C. 2009. Arbuscular mycorrhizal fungi and organic fertilizer influence photosynthesis, root phosphatase activity, nutrition, and growth of Ipomoea carnea ssp. Fistulosa. Photosynthetica. vol 47: 1-10. doi: https://doi.org/10.1007/s11099-0090003-X.

Basiron Y. 2007. Palm oil production through sustainable plantations. European Journal of Lipid Science and Technology. vol 109(4): 289-295. doi: https://doi.org/10.1002/ejlt.200600223

Bucher M. 2007. Functional biology of plant phosphate uptake at root and mycorrhizae interfaces. J. New Phytologist. vol 173(1): 11-26. doi: https://doi.org/10.1111/j.14698137.2006.01935.x. 
Dreyer B, Pérez-Gilabert M, Olmos E, Honrubia M, Morte A. 2008. Ultrastructural localization of acid phosphatase in arbusculate coils of mycorrhizal Phoenix canariensis roots. Physiologia Plantarum. vol 132(4): 503513. doi: https://doi.org/10.1111/j.13993054.2007.01034.x.

Eom AH, Hartnett DC, Wilson GWT. 2000. Host plant species effects on arbuscular mycorrhizal fungal communities in tallgrass prairie. Oecologia. vol 122(3): 435-444.

doi: https://doi.org/10.1007/s004420050050.

Ermawati T, and Saptia Y. 2013. Kinerja ekspor minyak kelapa sawit Indonesia. Buletin Ilmiah Litbang Perdagangan. vol 7(2): 129-147.

Euler M, Hoffmann MP, Fathoni Z, Schwarze S. 2016. Exploring yield gaps in smallholder oil palm production systems in eastern Sumatra, Indonesia. Agricultural Systems. vol 146:111-119. doi: https://doi.org/10.1016/j.agsy.2016.04.007

Gaur A, and Adholeya A. 2002. Arbuscular mycorrhizal inoculation of five tropical fodder crops and inoculums production in marginal soil amended with organic matter. Biology and Fertility of Soils. vol 35(3): 214-218. doi: https://doi.org/10.1007/s00374-0020457-5.

Goh KJ, and Po SB. 2005. Fertilizer recommendation systems for oil palm: estimating the fertilizer rates. In Proceedings of MOSTA Best practices workshops-agronomy and crop management. Malaysian Oil Scientists' and Technologists' Association. pp 1-37.

Jaiti F, Meddich A, Hadrami IE. 2007. Effectiveness of arbuscular mycorrhizal fungi in the protection of date palm (Phoenix dactylifera L.) against bayoud disease. Physiological and Molecular Plant Pathology. vol 71(4-6): 166-173. doi:

https://doi.org/10.1016/j.pmpp.2008.01.00 2.

Joner EJ, van Aarle IM, Vosatka M. 2000. Phosphatase activity of extra-radical arbuscular mycorrhizal hyphae: A review. Plant and Soil. vol 226(2): 199-210. doi: https://doi.org/10.1023/A:1026582207192

Liu A, Plenchette C, Hammel C. 2007. Soil nutrient and water providers: How arbuscular mycorrhizal mycelia support plant performance in resource limited world. In: Hamel, C., Plenchette, C., (Eds.) mycorrhizae in crop production. Binghampton: Haworth Food and Agricultural Products Press. pp. 37-66.

Phosri C, Rodriguez A, Sanders IR, Jeffries P. 2010. The role of mycorrhizae in more sustainable oil palm cultivation. Agriculture, Ecosystem and Environment. vol 135(3): 187-193. doi: https://doi.org/10.1016/j.agee.2009.09.006

Ramos-Zapata J, Orellana R, Guadarrama P, Medina-Peralta S. 2009. Contribution of mycorrhizae to early growth and phosphorus uptake by a neotropical palm. Journal of Plant Nutrition. vol 32(5): 855866.

Ruiz-Lozano JM, and Azcón R. 2000. Symbiotic efficiency and infectivity of an autochthonous arbuscular mycorrhizal Glomus sp. from saline soils and Glomus deserticola under salinity. Mycorrhiza. vol 10(3): 137-143. doi: https://doi.org/10.1007/s005720000075.

Sun CX, Cao HX, Shao HB, Lei XT, Xiao Y. 2011. Growth and physiological responses to water and nutrient stress in oil palm. African Journal of Biotechnology. vol 10(51): 10465-10471. doi: http://dx.doi.org/10.5897/AJB11.463.

Wahid MB. Abdullah SNA, Henson IE. 2005. Oil Palm. Plant Production Science. vol 8(3): 288-297. doi: https://doi.org/10.1626/pps.8.288.

Webb MJ. 2009. A conceptual framework for determining economically optimal fertiliser use in oil palm plantations with factorial fertiliser trials. Nutrient Cycling in Agroecosystems. vol 83(2): 163-178. doi: https://doi.org/10.1007/s10705-0089207-x.

Woittiez LS, van Wijk MT, Slingerland M, van Noordwijk M, Giller KE. 2017. Yield gaps 
in oil palm: a quantitative review of contributing factors. European Journal of
Agronomy. vol 83:57-77. doi: https://doi.org/10.1016/j.eja.2016.11.002. 